\title{
Advancing the Engineering Field: Opportunities to Support Transfer Stu- dents
}

\section{Dr. Vukica M. Jovanovic, Old Dominion University}

Dr. Vukica Jovanovic is an Associate Professor of Engineering Technology in Mechanical Engineering Technology Program. She holds a Ph.D. from Purdue University in Mechanical Engineering Technology, focus on Digital Manufacturing. Her research is focused on mechatronics, digital manufacturing, digital thread, cyber physical systems, broadening participation, and engineering education. She is a Director of Mechatronics and Digital Manufacturing Lab at ODU and a Lead Faculty of Mechatronics area of specialization. She worked as a Visiting Researcher at Commonwealth Center for Advanced Manufacturing in Disputanta, VA on projects focusing on digital thread and cyber security of manufacturing systems. She has funded research in broadening participation efforts of underrepresented students in STEM funded by Office of Naval Research, focusing on mechatronic pathways. She is part of the ONR project related to the additive manufacturing training of active military. She is also part of the research team that leads the summer camp to nine graders that focus on broadening participation of underrepresented students into STEM (ODU BLAST).

\section{Dr. Narketta Sparkman-Key, Old Dominion University}

Dr. Narketta Sparkman-Key is an Assistant Professor of Human Services in the Counseling and Human Services department at Old Dominion University. She holds Doctorate of Philosophy in Human Services with a focus on Social and Community Services from Capella University. Her research focuses on furthering the professional identity of human service practitioners and define practice with diverse populations. She has a special interest in the education of non-traditional students and has targeted grants to advance the education and research to meet the needs of nontraditional students. She has over 20 years in the field of human services. She is formerly the membership chair of the National Organization for Human Services and reviewer for the Council for Standards in Human Service Education. She serves on the human service advisory committee for the City of Chesapeake and a certified parent educator through the Virginia Supreme Court. She holds the HS-BCP(Human Services Board Certified Practitioner) designation. She has also developed and led a service learning focused study abroad in Jamaica where she annually accompanies human service students to Montego Bay, Jamaica to develop self esteem among pregnant teens. Dr. Sparkman-Key received consecutive university grants to support her service to teen moms in Jamaica. She has been recognized for her accomplishments by the National Organization of Human Services and by former students who nominated her as "Most Inspiring Faculty. She was awarded the 2016 Broderick Diversity Champion award, 2016 Top 40 Under 40 Hampton Roads Award and the 2016 Undergraduate Research Mentor Award. She has also been featured on Health and Human Services radio to share her perspectives on human services.

\section{Dr. Konstantin P. Cigularov, Old Dominion University}

Dr. Konstantin Cigularov is an Associate Professor of Industrial-Organizational Psychology in the College of Sciences at Old Dominion University. He holds a Ph.D. from Colorado State University in IndustrialOrganizational Psychology and a B.S. in Banking and Finance from the University of Economics in Bulgaria. As the Director of the Safety Management \& Applied Research Lab, Dr. Cigularov has investigated various organizational issues related to leadership and culture, employee burnout and stress, as well as training programs and interventions. Dr. Cigularov has extensive experience with program design and evaluation and he has consulted numerous organizations, including the Colorado Department of Public Health and Environment, on designing, evaluating, and disseminating effective interventions and training programs. He has expertise in both quantitative and qualitative research methodologies, which he uses to better understand and help organizations create and engender safer, healthier, and more fulfilling workplaces.

Mrs. Daniela Cigularova

Ms. Bonita G. Anthony, Old Dominion University 


\title{
Advancing the Engineering Field: Opportunities to Support Transfer Students
}

\begin{abstract}
:
Advancements in technology have made it vital that technicians advance their skills to stay current and competitive in the job market. Many technicians choose to transfer to baccalaureate programs in engineering and other STEM fields in order to advance their skills. As a result, engineering programs usually have a large population of transfer students. Many of transfer students are studying while employed in the field and some juggle a career and family while advancing their education. Accordingly, transfer students face various issues when transferring to different university settings. Some of these issues are related to embeddedness into the university community while other issues are more personal in nature. Various academic support programs are focused on providing transfer students with information such as how to enroll in their classes, how to enable them to be successful in their academic program, and how to persist in the program. However, adapting to the new educational environment often means that they have to establish new mentoring relationships, develop a new social peer network, and search for internships or co-op opportunities. Majority of the transfer students enrolled in a midsize institution's engineering technology program are "non-traditional" students, e.g., veterans, adult students, working students, students with families, etc. This paper discusses specific needs of STEM transfer students, identifies challenges they face, and provides an overview of some of the programming that can be implemented at mid-sized universities that address these needs.
\end{abstract}

\section{Introduction}

Understanding challenges that transfer students face when entering undergraduate engineering technology programs is especially important due to the lack of highly skilled technical workforce needed in the area of advanced manufacturing and other high-tech industries that employ engineering technology graduates with bachelor's degrees [1]. In order to diversify the field and supply competent professionals for some of these advanced engineering roles, it is important that we bridge the gap between onboarding of transfer students and graduation from four-year institutions. Underrepresented students account for a large percentage of the overall transfer student population [2,3]. Innovation in onboarding practices and in recruitment of underrepresented and nontraditional students would benefit the field greatly and address the gap that exist in the engineering workforce. Research suggests that some programs, specifically focused on transfer students, aim to improve mentorship networks for students who are transferring and target first generation transfer students and their specific needs [4]. Various approaches to increasing transfer student success try to accommodate specific needs of students who are working full time, raising a family, and trying to advance their careers by furthering their education [4].

\section{Transfer Students}

The President's Council of Advisors on Science and Technology (2012) recommended that universities can increase the overall number of engineering graduates by focusing on diversifying pathways. According to the National Center for Education Statistics, 57\% of Hispanic students and 52\% of African American students in undergraduate education during Fall 
2014 were enrolled in two-year public colleges [5]. There has been an increased interest in transfer students in engineering and science fields that has prompted research to further understand these students' needs and barriers. Researchers have found that institutional policies had an impact on transfer student success and attainment [5]; that transfer students did not avail themselves to certain opportunities due to their distinctive characteristics; and in-depth advising was important for transfer student success [6]. Researchers have also noted that academic success of Latino engineering transfer students could be attributed to utilizing peer social support networks, obtaining internships, improving study skills, and maintaining mentoring relationships developed at the community college level [7]. In addition, various reports on African-American engineering transfer students suggested that peer social support networks were instrumental in their persistence in the field $[8,9]$. Furthermore, academic support to engineering and science transfer students from underrepresented populations has been found to result in increased graduation rate and graduate school enrollment [10-13].

\section{Transfer Students at Mid-Sized Universities}

Through the Guaranteed Admission Agreement (GAA), students who transfer to a midsized university [blind-review] meet the university's general education requirements and are granted junior standing. As part of the GAA agreement, a mid-sized university must annually explore opportunities to develop and approve program specific transfer articulation agreements. Articulation agreements are used to ease the transfer process between community college and the mid-sized university. The agreements specifically tell students what courses would transfer and how they would be accepted by the university. This transparency ensures that students are on the right track towards graduating from the university.

Despite the efforts to ease the transfer process, the need for increased attention and resources devoted to transfer students is particularly evident and critical at mid-sized universities. In a recent study conducted by a mid-sized university examining the experiences of their transfer students, the following university-focused recommendations were offered: (a) provide resources to all transfer students on academic warning to enhance their time management, organizational, and attentional skills (e.g., a one-credit course or workshop); (b) include self-efficacy building components in transfer student-oriented programs through interactions with successful transfer students, individual recognition and encouragement, and creating opportunities for early successes by thoughtful and effective advising in their first semesters at the university; (c) provide opportunities and encourage transfer students to interact with faculty; (d) increase awareness among faculty and staff about the unique needs and challenges of transfer students and how to address them; (e) collaborate with transferring institutions to improve the process effectiveness and preparation of incoming students, and (f) establish a centralized space with resources specifically geared toward transfer students [20]. The study disclosed that not only were transfer students struggling to meet the demands of the university setting, but there was also a lack of understanding by the instructors of the unique challenges faced by transfer students [20].

In addition, most recent statistics from the National Student Clearinghouse Research Center indicate that one in three college students who start their education at a two-year college complete it at a different institution [14]. Moreover, many students who start their education on a two-year public institution often need even six years to complete their A.S. and B.S. The above findings represent a significant concern and highlight the need to pay increased attention to the 
successful adjustment, retention, and graduation of transfer students. Universities must pay attention to the needs of their transfer student population by means of developing relevant strategic goals and priorities that ensure support and resources to promote transfer student success. This study provides two examples of ways midsize higher education institutions can support engineering transfer students in efforts to increase retention and reduce time to degree completion.

\section{Ways to Support Engineering Transfer Students}

\section{Peer Support Network}

Focusing on the needs of subpopulations found within a body of transfer students is one way to address underrepresented populations in engineering. Peer support networks have been found to benefit underrepresented populations and specifically tailoring the peer support network towards the needs of a specific subpopulation could increase retention [15]. In a study of a peer support network for women, women were given opportunities to engage with other women in STEM going through similar experiences. The peer mentoring offered helped address isolation barriers and the lack of successful female role models at the graduate level by developing relationships and building support networks with other women at similar stages in their careers [15]. Researchers have suggested that peer mentoring could provide role models for female faculty in engineering and could have positive impacts on their career advancement [16].

Another important issue is the perception of someone's role in the society. The development of female leaders in engineering involves more than just technical skill development. Equally important to obtaining and succeeding in leadership roles is developing support networks with peers. Such networks are important for women to develop early in their careers to help build their confidence, provide them with personal and professional support, and prevent them from "leaking" from the engineering pipeline [18]. To counteract the problem of women dropping out of STEM courses, the establishment of mentor schemes has been used and some studies have shown success with such schemes [18]. The support group provides the program participants with the opportunity to discuss and process challenges they may be facing as they enter the STEM fields so that they may be able to have their concerns heard and they can develop appropriate coping strategies. The building of a peer support network for minority women in STEM majors through such support groups may increase the retention and success of these students [19].

Similar results were found with racial minority students [20-22]. In these studies, the authors concluded that students overcame barriers encountered when transferring as a result of peer support networks, where the peer support network was the most significant element in addition to other supports [20-22]. Thus, it would seem that peer support networks are beneficial to multiple types of underrepresented populations in Engineering.

Students with effective networks of support, especially support provided by their peers, are seemingly more likely to have better motivation and persistence, and are willing to work collaboratively [15, 16, 18, 20-22]. Additionally, interacting with peers can fortify the learning process and make learning more enjoyable [23]. However, it may be difficult for students to create and maintain such support networks on their own [24]. Therefore, helping students create such peer support networks should be a task for university officials, who aim to improve the retention and success rate in STEM courses. University officials can create and foster a learning 
community with better cohesion in the class where students are encouraged and motivated to break through the social barrier, which in turn can speed up the process of building effective peer support network [25] .

\section{Learning Communities}

Various studies have shown that participating in a learning community is positively linked to engagement as well as student self-reported outcomes and overall satisfaction with college. [26]. Learning communities take different forms and are developed in different ways: (a) students enrolled in two or more courses linked together with a common theme, (b) classroom community in which the classroom serves to build community through cooperative learning techniques and group processing, (c) residential learning communities in which students physically live in the same place and take two or more courses together, and (d) learning communities specifically designed to target certain groups i.e. underrepresented or academic interest. Current trends in the engineering industry are leading to the merging of engineering fields which require engineers to have more integrated curricula. Such curricula can include learning communities exposing students to interdisciplinary and social connections that are related to increased retention and student performance [27]. Learning communities have higher success rates in underrepresented student groups and engender collaborative learning, which in turn is associated with a number of positive outcomes including improved academic performance, improved retention, enhanced student satisfaction with the learning experience, improved oral communication skills, and higher student self-esteem [28].

\section{Conclusion}

Although peer support and learning communities have been recognized as important for student success for transfer students, there are still significant challenges in their implementation. Mid-sized universities often gain a significant number of transfer students majoring in engineering, especially in urban areas where students have more access to community colleges. The growth of the engineering field and technological advancements have called for more skilled specialists especially in engineering technology, making it advantageous for students to obtain a four-year degree in the field, often as transfer students in four-year colleges and universities. However, there have been increased challenges in retaining transfer students in engineering. At the same time, programs for transfer students often fail to address the needs of underrepresented students due to lack of resources and/or understanding of their needs. This paper describes innovative ways to meet the needs of transfer students, increase their retention, and provide support to underrepresented populations. Research contends that peer support networks and learning communities are beneficial to transfer students as they foster an environment of community building, mentorship, academic success, as well as attention to the unique needs of transfer students. Engineering programs should consider developing peer support networks to facilitate the onboarding of transfer students into the university community by providing them with mentorship and support from peers with similar interests and characteristics. In addition, engineering programs should consider the development of learning communities centered around transfer students that would offer opportunities for mentorship and foster relationship and community building. 


\section{References}

[1] S. Olson and D. G. Riordan, "Engage to Excel: Producing One Million Additional College Graduates with Degrees in Science, Technology, Engineering, and Mathematics. Report to the President," Executive Office of the President, 2012.

[2] J. Fredrickson, "Today's transfer students: Who are they?," Community College Review, vol. 26, pp. 43-54, 1998.

[3] L. E. Malcom, "Charting the pathways to STEM for Latina/o students: The role of community colleges," New Directions for Institutional Research, vol. 2010, pp. 29-40, 2010.

[4] L. J. Griffin, "Bridging the Support Gap for First Generation College Students with Community Mentor Programs," 2015.

[5] A. M. Ogilvie, D. B. Knight, M. J. Borrego, A. A. Fuentes, P. A. Nava, and V. E. Taylor, "Understanding and diversifying transfer student pathways to engineering degrees: An update on project findings," in 2017 ASEE Annual Conference \& Exposition, Columbus, Ohio, 2017.

[6] T. J. Rhine, D. M. Milligan, and L. R. Nelson, "Alleviating transfer shock: Creating an environment for more successful transfer students," Community College Journal of Research \& Practice, vol. 24, pp. 443-453, 2000.

[7] S. M. Lord, M. M. Camacho, R. A. Layton, R. A. Long, M. W. Ohland, and M. H. Wasburn, "Who's persisting in engineering? A comparative analysis of female and male Asian, black, Hispanic, Native American, and white students," Journal of Women and Minorities in Science and Engineering, vol. 15, 2009.

[8] E. J. Miller, Understanding Social Integration and Student Involvement as Factors of Self-Reported Gains for African American Undergraduate Women: University of South Florida, 2012.

[9] D. Wilson, From aspiration to attainment: African American community college transfer student experiences through baccalaureate degree attainment: University of North Texas, 2013.

[10] M. Ong, C. Wright, L. Espinosa, and G. Orfield, "Inside the double bind: A synthesis of empirical research on undergraduate and graduate women of color in science, technology, engineering, and mathematics," Harvard Educational Review, vol. 81, pp. 172-209, 2011.

[11] A. Monte and G. Hein, "An Innovative Program to Support Undergraduate Engineering Students from Underrepresented Groups," age, vol. 9, p. 1, 2004.

[12] M. R. Anderson-Rowland, "Transfer students: Lessons learned over 10 years," in 2014 ASEE Annual Conference \& Exposition, 2014, pp. 24.1275. 1-24.1275. 8.

[13] J. Chapa and B. De La Rosa, "The problematic pipeline: Demographic trends and Latino participation in graduate science, technology, engineering, and mathematics programs," Journal of Hispanic Higher Education, vol. 5, pp. 203-221, 2006.

[14] D. Shapiro, A. Dundar, P. K. Wakhungu, X. Yuan, and A. Harrell, "Transfer and mobility: A national view of student movement in postsecondary institutions, fall 2008 cohort," Signature Report, vol. 9, 2015. 
[15] S. Bhatia and J. P. Amati, "'If These Women Can Do It, I Can Do It, Too": Building Women Engineering Leaders through Graduate Peer Mentoring," Leadership and Management in Engineering, vol. 10, pp. 174-184, 2010.

[16] N. C. Chesler, P. B. Single, and B. Mikic, "On Belay: Peer-Mentoring and Adventure Education for Women Faculty in Engineering," Journal of Engineering Education, vol. 92, pp. 257-262, 2003.

[17] L. D. Patton and S. R. Harper, "Mentoring relationships among African American women in graduate and professional schools," New Directions for Student Services, vol. 2003, pp. 67-78, 2003.

[18] A. Craig, J. Fisher, A. Scollary, and M. Singh, "Closing the gap: Women education and information technology courses in Australia," Journal of Systems and Software, vol. 40, pp. 7-15, 1998.

[19] E. I. Edwards, STEMS4ME: A community college connection program for minority women in STEM fields: Saint Mary's College of California, 2015.

[20] K. T. Granger, African American engineering students at river city community college: Factors that improve transfer to four-year engineering degree programs: University of Southern California, 2011.

[21] R. Rivera, "Latino community college transfer students in engineering: Transition experiences and academic success at a large research university," Arizona State University, 2007.

[22] S. E. Rocheleau, "Effect of non-cognitive and social environmental factors on the retention of under-represented minority students in engineering and technology-related disciplines," 2004.

[23] C. Li, Z. Dong, R. Untch, M. Chasteen, and N. Reale, "Peerspace-an online collaborative learning environment for computer science students," in Advanced Learning Technologies (ICALT), 2011 11th IEEE International Conference on, 2011, pp. 409-411.

[24] P. C. Blumenfeld, E. Soloway, R. W. Marx, J. S. Krajcik, M. Guzdial, and A. Palincsar, "Motivating project-based learning: Sustaining the doing, supporting the learning," Educational psychologist, vol. 26, pp. 369-398, 1991.

[25] Z. Dong, C. Li, and R. H. Untch, "Build peer support network for CS2 students," in Proceedings of the 49th Annual Southeast Regional Conference, 2011, pp. 42-47.

[26] C.-M. Zhao and G. D. Kuh, "Adding value: Learning communities and student engagement," Research in higher education, vol. 45, pp. 115-138, 2004.

[27] J. E. Froyd and M. W. Ohland, "Integrated engineering curricula," Journal of Engineering Education, vol. 94, pp. 147-164, 2005.

[28] G. S. May and D. E. Chubin, "A retrospective on undergraduate engineering success for underrepresented minority students," Journal of Engineering Education, vol. 92, pp. 2739, 2003. 